Epidemiology and Infection

cambridge.org/hyg

\section{Erratum}

Cite this article: Mboussou F et al (2019). Infectious disease outbreaks in the African region: overview of events reported to the World Health Organization in 2018 - ERRATUM. Epidemiology and Infection 147, e307, 1. https://doi.org/10.1017/S0950268819002061

\title{
Infectious disease outbreaks in the African region: overview of events reported to the World Health Organization in 2018 - ERRATUM
}

F. Mboussou, P. Ndumbi, R. Ngom, Z. Kassamali, O. Ogundiran, J. Van Beek,

G. Williams, C. Okot, E. L. Hamblion and B. Impouma

doi: 10.1017/S0950268819001912, Published online by Cambridge University Press, 11 November 2019

The above article was originally submitted to Epidemiology \& Infection with Z. Kassamali's name given as Z. Kamassali. This has been rectified in the online PDF and HTML copies.

\section{Reference}

Mboussou F et al. (2019). Infectious disease outbreaks in the African region: overview of events reported to the World Health Organization in 2018. Epidemiology and Infection 147, e299, 1-8. https://doi.org/10.1017/ S0950268819001912 (c) The Author(s) 2019. This is an Open Access article, distributed under the terms of the Creative Commons AttributionNonCommercial-ShareAlike licence (http:// creativecommons.org/licenses/by-nc-sa/4.0/), which permits non-commercial re-use, distribution, and reproduction in any medium, provided the same Creative Commons licence is included and the original work is properly cited. The written permission of Cambridge University Press must be obtained for commercial re-use.

\section{CAMBRIDGE UNIVERSITY PRESS}

